\title{
Keberhasilan Pengembangan Ternak Sapi Potong Melalui Pola Pengembangan Modal Usaha (KUPS)
}

\section{The success of Beef Cattle Development Through Venture Capital Development Patterns (KUPS)}

\section{Bambang Winarso}

Pusat Sosial Ekonomi dan Kebijakan Pertanian, Badan Litbang Pertanian, Bogor.

\begin{abstract}
Government policies in helping dairy farmers in an effort to meet the capital needs of breeding them is through a policy program Kredit Usaha Pembibitan Sapi (KUPS). KUPS is skim credit used to finance the development of cattle breeding and dairy cattle by businesses with subsidized interest rates. The problems that the distribution KUPS seen through the eyes of a banking institution is (a) the availability of information prospective potential borrowers are still minimal (b) the legality of ownership of assets (c) cattle breeding company still slightly. KUPS program has been rolled out since 2010, meaning that until 2014 the program has been running five (5) years. But the realization of its lending until September 2014, reached $15.42 \%$ of the amount of the ceiling of $\mathrm{Rp} 4.00$ trillion. The realization can be said to be too small or fails. Of course there is the small achievements of the bank as an institution that is authorized to distribute funds would need to act professionally and carefully. Given the experience of lending a mass program past such cases KUT (Kredit Usaha Tani) end up with less encouraging. Instead the main purpose of the program is awakened, just the opposite of credit are understood as government social assistance by the debtor (the farmer). So it is very natural that the bank hand is always cautious. The study was conducted in West Sumatra in 2014, data analysis used data a simple cross-tabulation using the primary data and secondary data from interviews with respondents either breeders penmanfaat KUPS and banking institutions as channeling KUPS
\end{abstract}

Keywords: Beef Cattle Development, Venture Capital, KUPS

Diterima:4-12-2014 ditisetujui 07-02-2015

\section{PENDAHULUAN}

Kebijakan pemerintah kaitannya dengan usaha pembibitan sapi potong mengacu kepada Undang-Undang No 18/2009, bahwa Pemerintah berkewajiban untuk melakukan pengembangan usaha pembibitan dengan melibatkan peran serta masyarakat untuk menjamin ketersediaan benih, bibit dan bakalan. Disisi lain kebijakan pemerintah yang berkaitan dengan masalah penguatan modal usaha adalah kebijakan pengembangan usaha budidaya ternak sapi potong melalui bantuan modal KUPS. Dalam upaya mendorong pelaku usaha pembibitan ternak sapi, salah satu kebijakan yang diambil pemerintah adalah ditetapkannya skim kredit yang bersumber dari perbankan seperti yang telah 

ditetapkan oleh Peraturan Menteri Keuangan No. 131/MPK.05/2009 tentang Kredit Usaha Pembibitan Sapi (KUPS), Juncto Peraturan Menteri Keuangan No. 241/PMK.05/2011 tentang Perubahan Atas Peraturan Menteri Keuangan No. 131/PMK.05/2009. Dalam peraturan tersebut yang dimaksud Usaha Pembibitan Sapi adalah suatu usaha kegiatan budidaya yang menghasilkan bibit ternak sapi.

KUPS merupakan skim kredit Perbankan dengan suku bunga bersubsidi yang dikeluarkan melalui Peraturan Menteri Keuangan No. 131/PMK.05/2009 tentang Kredit Usaha Pembibitan Sapi (KUPS) tanggal 18 Agustus 2009. Untuk mempermudah pelaksanaannya maka Menteri Pertanian mengeluarkan Permentan No. 40/Permentan/PD.400/9/2009, tentang Pedoman Pelaksanaan KUPS, tertanggal 8 September 2009. Dengan dikeluarkannya 2(dua) buah peraturan tersebut maka diharapkan usaha pembibitan sapi yang dilakukan oleh pihak swasta/koperasi dapat berjalan baik. Mengacu pada peraturan KUPS, diisyaratkan swasta atau koperasi maupun kelompok yang memanfaatkan skim kredit tersebut harus bermitra/kerjasama dengan kelompok peternak/gabungan kelompok peternak dengan prinsip saling menguntungkan dimana swasta/koperasi berperan sebagai Pembina/pengayom kelompok/gabungan kelompok.

Sampai dengan tahun 2014 ada duabelas bank yang telah sepakat untuk menyalurkan KUPS melalui Perjanjian Kerjasama Pendanaan (PKP) dengan Kementerian Keuangan, yaitu (a) Bank Umum, terdiri atas Bank BRI, Mandiri, BNI, Bukopin, Bank Syariah Mandiri, dan (b) Bank Pembangunan Daerah (BPD) yaitu BPD Jateng, BPD DIY, BPD Jatim, BPD Sumut, Bank Jambi dan Bank Nagari Sumatera Barat. dana yang terkumpul dari 12 Bank tersebut adalah sebesar Rp. 4,00 trilyun. Suku bunga ditentukan sebesar 5\% per tahun dalam jangka waktu kredit paling lama 6 tahun, dengan masa tenggang (grace periode) paling lama 24 bulan. Sasaran KUPS adalah tersedianya satu juta ekor sapi dalam kurun waktu 5 tahun (200.000 ekor/tahun). Sapi induk tersebut berupa sapi betina bunting atau siap bunting, berasal dari sapi impor, turunan impor atau sapi lokal terutama sapi Bali. Besarnya Plafon kredit maksimal Rp 66,31 milyar per pelaku usaha baik yang dilakukan oleh perusahaan pembibitan, koperasi maupun kelompok/gabungan kelompok peternak. KUPS difasilitasi dengan Suku Bunga Kredit maksimal sebesar suku bunga penjaminan Bank (LPS) + 6\%. Sedangkan Suku Bunga Petani/Peternak maksimal 5\% (Ditjen Peternakan dan Kesehatan Hewan, 2010).

Dalam hal keberadaan KUPS, maka Peran Pemerintah diantaranya adalah (a) Kementerian Keuangan menetapkan bank pelaksana, melakukan kerjasama dengan Bank Pelaksana, menetapkan plafon per Bank, menyediakan dan membayar subsidi bunga, menilai kepatuhan penyaluran KUPS.

(b) Mentan,Menkeu, Gubernur, Bupati/Walikota melakukan pembinaan dan pengendalian pelaksanaan KUPS. (c) Dinas Kab/Kota: memberikan rekomendasi perusahaan pembibitan, koperasi, kelompok/ gabungan kelompok sebagai peserta KUPS, mengetahui kontrak kemitraan, monitoring dan evaluasi, menyampaikan laporan kepada Dinas Prov. (d) Ditjen Peternakan melakukan monitoring dan evaluasi. Permasalahan bahwa penyaluran KUPS menurut BI diantaranya bahwa permasalahan yang dapat dijumpai debitur adalah (a) Ketersediaan informasi calon debitur potensial (b) Legalitas kepemilikan aset UMKM, (c) Sulit mendapatkan perusahaan inti (close system), (d) Perusahaan pembibitan sapi masih sedikit. Sementara untuk keamanan skim kredit maka diperlukan asuransi kematian ternak. Dilihat dari posisi Bank/Dinas, maka resiko yang cukup tinggi adalah (a) Resiko kematian ternak dan (b) Risiko kegagalan usaha dari para debitur (Sumber Bank Indonesia, 2012).

Mengingat KUPS adalah program pengembangan usaha pembibitan ternak sapi potong yang sumber dananya dari bank itu sendiri. Sehingga amatlah wajar apabila pihak bank senantiasa bersikap hati-hati.

Kredit adalah penyediaan uang atau tagihan yang dapat dipersamakan dengan itu, berdasarkan persetujuan atau kesepakatan pinjam meminjam antara bank dengan pihak lain yang mewajibkan 
pihak peminjam melunasi hutangnya setelah jangka waktu tertentu dengan pemberian bunga (Kementerian Negara Koperasi dan Usaha Kecil dan Menengah, 2009). Kaitannya dengan program KUPS, lembaga bank milik pemerintah dipercaya untuk ikut langsung terlibat dalam penyaluran kredit program KUPS kepada peternak, pengusaha ternak atau kepada kelompok ternak yang bergerak dibidang usaha perbibitan ternak khususnya sapi potong dan sapi perah. Bahwa untuk menindak lanjuti tugas tersebut pihak Bank yang ditunjuk telah menyiapkan beberapa persyaratan teknis maupun manajemen yang harus dipenuhi oleh setiap calon debitur yang akan memanfaatkan skim dana pinjaman KUPS tersebut. Beberapa peraturan yang diterapkan kepada calon peminjam dana KUPS ditentukan berdasarkan klasifikasi sesuai dengan keragaan lembaga bisnis yang ada yaitu (a) perusahaan yang bergerak dibidang perbibitan ternak sapi, (b) koperasi yang bergerak dibidang perbibitan ternak sapid an (c) Kelompok tani/ternak.

Penerapan peraturan yang dikenakan oleh bank kepada calon bank bervariasi disesuaikan dengan calon debitur/peminjam. Bagi Perusahaan perbibitan ternak sapi yang akan mengajukan pinjaman KUPS, maka syarat-syarat yang harus dipenuhi diantaranya adalah sebagai berikut: Harus berbadan hukum, dimana usaha yang dilakukan memenuhi "prosedur baku" tentang perbibitan ternak sapi. Disamping itu harus bermitra dengan kelompok tani ternak/gapoktannak bagi perusahaan yang akan mengajukan KUPS. Mendapat rekomendasi dari pemerintah kota/kabupaten dalam hal ini adalah Dinas Peternakan dan Kesehatan Hewan kabupaten dan Dinas Peternakan dan Kesehatan Hewan di tingkat provinsi setempat serta mendapat rekomendasi dari Ditjen Peternakan. Telah beroperasi sesuai dengan bidangnya minimal 2 tahun. Tidak termasuk dalam "daftar hitam" bank. Bertindak sebagai afalis

Sementara untuk lembaga Koperasi yang bergerak di bidang perbibitan ternak sapi potong dan ingin mengajukan KUPS, maka syarat yang harus dipenuhi diantaranya adalah hampir sama dengan perusahaan, hanya saja perlu ditambahi dengan dalam lembaga koperasi tersebut ada pengurus aktif, anggota terdiri dari para peternak sapi, ada izin usaha dan memenuhi prosedur baku perbibitan ternak, mendapat rekomendasi dari Dina yang sama baik di tingkat kabupaten maupun provinsi dan Ditjend peternakan serta tidak termasuk dalam daftar hitam bank. Sementara untuk kelompok persyaratannya adalah jumlah anggota minimal 5 peternak, terdaftar pada Dinas Peternakan dan Kesehatan Hewan setempat dan memiliki peraturan dan ada pengurus aktif.

Permasalahan yang dihadapi perbankan dilapangan dalam melaksanakan penyaluran dana KUPS memang tidak sedikit. Pemahaman tentang juklak dan juknis oleh petugas bank juga belum sepenuhnya dapat dipahami terutama menyangkut masalah teknis peternakan. Sehingga pihak bank sendiri perlu bersikap hati-hati dalam menterjemahkan juklak dan juknis tersebut. Mengingat ada istilah-istilah yang memang perlu dipahami dengan benar, misalnya "prosedur baku pembibitan". Selain itu istilah penggunaan "chip" pada ternak, istilah-istilah seperti tersebut diatas tampaknya masih banyak yang awam. Baik bentuk, kegunaan serta fungsi dari pada alat tersebut. Disamping adanya istilah-istilah teknis peternakan lainnya yang terkadang membuat pihak petugas bank perlu hati-hati untuk memahaminya.

\section{METODE}

Penelitian ini dilakukan di wilayah Sumatera Barat terutama di wilayah-wilayah kabupaten yang dilayani oleh program KUPS. Penelitiannya sendiri dilakukan pada awal tahun 2014. Beberapa 
kelompok tani peserta program KUPS merupakan responden yang digali informasinya disamping beberapa key informan baik di Dinas Peternakan dan Kesehatan Hewan maupun di Bank Nagari selaku penyalur dana KUPS.

\section{PEMBAHASAN}

\section{a. Realisasi Capaian KUPS}

Program pengembangan modal usaha budidaya pembibitan ternak sapi melalui kebijakan skim kredit KUPS telah digulirkan sejak tahun 2010, artinya sampai dengan tahun 2014 ini program tersebut telah berjalan 5 (lima) tahun. Data tabel 1 menunjukkan bahwa realisasi kinerja penyaluran kredit tersebut tampaknya belum menggembirakan. Sampai dengan September 2014, realisasi dana kredit tersalur baru mencapai 15,42\% dari besarnya plafon senilai Rp 4 triliun yang tersalurkan lewat sepuluh bank penylur. Realisasi tersebut dapat dikatakan terlalu kecil untuk kepentingan pemanfaatan kredit bagi usaha pengembang budidaya pembibitan ternak sapi potong yang sebenarnya saat ini sedang digalakkan dalam upaya meningkatkan populasi.

Tabel 1 : Data Realisasi Kumulatif Penyaluran KUPS sampai dengan Bulan September 2014

\begin{tabular}{|c|c|c|c|c|c|}
\hline $\mathrm{NO}$ & BANK & PKP (Rp) & Realisasi Kredit (Rp) & $\%$ & Jumlah ternak \\
\hline 1 & BRI & 2.000 .000 .000 .000 & 110.636 .674 .000 & 5,53 & 8.500 \\
\hline 2 & $\mathrm{BNI}$ & 500.000 .000 .000 & 80.803 .939 .000 & 16,16 & 5.907 \\
\hline 3 & Bank Mandiri & 100.000 .000 .000 & 75.810 .425 .000 & 75,81 & 3.647 \\
\hline 4 & Bank Jatim & 1.030 .000 .000 .000 & 132.840 .349 .660 & 12,90 & 10.875 \\
\hline 5 & Bank Jateng & 50.000 .000 .000 & 17.568.727.000 & 35,14 & 1.515 \\
\hline 6 & Bank BPD DIY & 25.000 .000 .000 & 5.970 .000 .000 & 23,88 & 475 \\
\hline 7 & Bank Nagari & 55.000 .000 .000 & 40.005.359.000 & 72,74 & 3.855 \\
\hline 8 & Bank Sumut & 100.000 .000 .000 & 87.417.180.727 & 87,42 & 7.120 \\
\hline 9 & Bank BPD Bali & 60.000 .000 .000 & 61.840 .994 .575 & 103,07 & 6.374 \\
\hline 10 & Bank BPD NTB & 12.953 .000 .000 & 4.415 .100 .000 & 34,09 & 718 \\
\hline 11 & Bank Bukopin & 50.000 .000 .000 & 0 & 0 & 0 \\
\hline 12 & Bank BPD Jambi & 21.000 .000 .000 & 0 & 0 & 0 \\
\hline 13 & JUMLAH & 4.003 .953 .000 .000 & 617.308 .748 .962 & 15,42 & 48.986 \\
\hline
\end{tabular}

Sumber : Ditjend Peternakan dan Kesehatan Hewan, 2014

Kecilnya capaian kredit KUPS tersalur tersebut tentu beralasan, sebab bank selaku lembaga yang berwenang menyalurkan dana tentu perlu harus bertindak profesional dan hati-hati. Mengingat pengalaman penyaluran kredit program massal masa lalu seperti kasus KUT berakhir dengan kurang menggembirakan. Bukannya program tujuan utama yang terbangun, justru sebaliknya kredit tersebut dipahami sebagai bantuan sosial pemerintah oleh debitur (petani). Oleh karena itu untuk tidak terulang kembali kasus tersebut diatas, maka untuk menghidari kerugian bank, maka lembaga ini perlu selektif dalam upaya meminimalisir kerugian usaha.

Kaitannya dengan masalah diata dan guna mendukung program pemerintah dalam meningkatkan produksi peternakan sapi, PT Bank Negara Indonesia Tbk menyalurkan kredit usaha pembibitan sapi (KUPS). Pada awal tahun 2013 Bank tersebut mengucurkan kredit senilai Rp 42,5 miliar untuk pembiayaan pembibitan 3.000 ekor sapi, di Makassar. Komitmen BNI ini sebagai salah 
Bambang Winarso: Keberhasilan Pengembangan Ternak Sapi Potong Melalui Pola Pengembangan Modal

satu bentuk dukungan pemerintah dalam mencapai swasembada daging sapi dengan berkontribusi dalam meningkatkan jumlah populasi sapi di Indonesia. (Republika, 2014).

\section{b. Pentingnya KUPS}

Kelemahan modal merupakan kendala utama utk mengembangkan usaha bagi sebagian besar pelaku usaha budidaya sapi potong. Akan tetapi dengan persyaratan pinjaman kredit yang ketat maka sulit bagi pelaku usaha pembibitan sapi potong untuk mengembangkan usahanya. Pengembangan usaha pembibitan sapi potong dapat dilakukan dengan pemanfaatan dana KUPS asalkan diberi kelonggaran aplikasi, namun tidak menyimpang dari usaha pokok sebagai pembibitan sapi potong. Winarso (2012) mengemukakan bahwa alokasi kredit seyogyanya dapat digunakan untuk usaha ganda yaitu usaha pembibitan dan penggemukan dimana usaha ganda tersebut pada dasarnya memang banyak dilakukan oleh peternak sapi potong. Usaha pembibitan sapi potong masih dirasakan berat apabila dilakukan secara bisnis tunggal tanpa diimbangi dengan usaha lain seperti penggemukan atau usaha lainnya yang dapat mendukung upaya pemenuhan kebutuhan input produksi pembibitan. Hal ini disebabkan karena perputaran modal untuk usaha pembibitan sapi potong yang lemah.

Dalam upaya meningkatkan kinerja usaha budidaya ternak sapi potong khususnya usaha pembibitan, peternak masih dihadapkan pada berbagai kendala. Selain kendala lambannya perkembangan usaha, resiko usaha yang rawan juga kendala lemahnya penguasaan modal. Kelambanan maupun kerawanan usaha merupakan kendala yang sifatnya teknis, diantaranya adalah lamanya usaha untuk mendapatkan revenue yang disebabkan karena durasi produksi hasil ternak yang membutuhkan waktu lebih dari satu tahun dalam satu siklus produksi. Sementara kerawanan usaha cenderung disebabkan karena dalam usaha budidaya ternak sapi potong khususnya pembibitan masih dihadapkan beberapa permasalahan. Winarso (2012) juga mengemukakan bahwa ada beberapa permasalahan dalam usaha pembibitan sapi potong diantaranya adalah :

(i) Kegagalan kebuntingan yang disebabkan karena kegagalan dalam Inseminasi buatan kalau pembuahan ke sapi betina dilakukan secara IB. Tidak semua kegiatan IB mampu membuat sapi betina bunting. Hal ini dapat disebabkan karena (a) kwalitas traw yang tidak bagus, (b) karena masa birahi yang tidak terdeteksi oleh peternak sehingga masa birahinya lewat dan (c) adanya penyakit reproduksi dan penyebab lain sehingga IB yang dilakukan mengalami kegagalan.

(ii) Kematian janin diakibatkan karena ternak induk yang sedang bunting kekurangan gizi, ternak yang bunting terserang penyakit atau karena penyebab lainnya.

(iv) Kematian pedet setelah lahir, hal ini disebabkan karena tidak tercukupinya kebutuhan susu, pedet terserang penyakit, kecelakaan karena non teknis seperti terinjak/tertindih induknya dll.

(v) Kematian ternak bakalan, hal ini lebih disebabkan karena penyakit atau penyebab lain.

Sebelas bank pemerintah dan bank pembangunan daerah sudah menyediakan dana untuk itu, tetapi penyalurannya tersendat. Terkendala oleh aturan bank yang mempersyaratkan jaminan. Ini terjadi pada petani/peternak perorangan yang kecil-kecil, yang tidak berbadan hukum, tidak tergabung dalam kelompok, koperasi atau menjadi plasma perusahaan besar (Daud Sinjal; 2011).

\section{c.Permasalahan di lapangan}

Dalam upaya merealisir pencairan dana, maka bank tentu perpegang pada lima kaidah utama yang harus dimiliki oleh debitur yaitu karakter, kapasitas, kapital, kondisi dan kolateral (Afandi P, 2010) : 


\section{Karakter}

Merupakan data tentang kepribadian dari calon pelanggan seperti sifat-sifat pribadi, kebiasaan-kebiasaannya, cara hidup, keadaan dan latar belakang keluarga maupun hobinya. Kegunaan dari penilaian tesebut untuk mengetahui sampai sejauh mana iktikad/kemauan calon calon debitur untuk memenuhi kewajibannya (wiilingness to pay) sesuai dengan janji yang telah ditetapkan. Pemberian kredit atas dasar kepercayaan, sedangkan yang mendasari suatu kepercayaan, yaitu adanya keyakinan dari pihak bank bahwa calon debitur memiliki moral, watak dan sifat-sifat pribadi yang positif dan koperatif. Disamping itu mempunyai tanggung jawab, baik dalam kehidupan pribadi sebagai manusia, kehidupan sebagai anggota masyarakat, maupun dalam menjalankan usahanya. Karakter merupakan faktor yang dominan, sebab walaupun calon debitur tersebut cukup mampu untuk menyelesaikan hutangnya, kalau tidak mempunyai itikad yang baik tentu akan membawa kesulitan bagi bank dikemudian hari.

Karakter merupakan faktor penting dalam pemberian kredit, karena menyangkut kepribadian terutama menyangkut kejujuran dari calon debitur. Karacter calon debitur dapat dilihat dari dua faktor yakni (a) faktor internal, meliputi hal-hal yang langsung berkaitan dengan diri calon debitur seperti pendidikan, daftar riwayat hidup, (b) faktor eksternal adalah hal-hal yang muncul dari luar diri calon debitur dan bisa mempengaruhi perubahan sifat dan character calon debitur. Seperti faktor lingkungan baik itu lingkungan kehidupan sosial, lingkungan pekerjaan maupun lingkungan pergaulan. Adapun tujuan penelaahan karakter calon debitur tidak lain adalah untuk meminimalisir terjadinya resiko kredit yang kemungkinan akan muncul pada saat kredit sedang berjalan. Penelaahan karakter yang baik dan tepat merupakan salah satu indikasi untuk menentukan baik tidaknya kredit tersebut kelak.

Untuk melengkapi informasi menyangkut karakter, maka pihak bank juga dapat melakukan kegiatan check on the spot, yaitu meninjau langsung ke lokasi tempat tinggal calon debitur, maupun lokasi usaha dan lokasi agunan. Hal ini dilakukan untuk melihat kebenaran dari apa yang dikatakan oleh calon debitur pada saat wawancara sebelumnya. Untuk agunan diperlukan COS agar terdapat kesesuaian antara surat yang diagunkan dengan fisik agunan. Selain juga melakukan BI Checking guna melihat reputasi pinjaman calon debitur yang pernah ada apakah dalam keadaan lancar atau bermasalah, yangmana informasi tersebut didapat langsung dari Bank Indonesia. BI checking dapat dilihat dari dua sisi yakni: (a) sisi internal calon debitur dengan melihat data pinjaman nasabah menanyakan langsung ke cabang/capem yang terdekat dengan lokasi domisili atau lokasi usaha calon debitur. (b) Sisi eksternal untuk melihat reputasi pinjaman calon debitur yang informasinya didapatkan dari Bank Indonesia.

\section{Kapasitas}

Capacity dalam hal ini merupakan suatu penilaian kepada calon debitur mengenai kemampuan melunasi kewajiban-kewajibannya dari kegiatan usaha yang dilakukannya yang akan dibiayai dengan kredit dari bank. Jadi jelaslah maksud penilaian dari terhadap capacity ini untuk menilai sampai sejauh mana hasil usaha yang akan diperolehnya tersebut akan mampu untuk melunasinya tepat pada waktunya sesuai dengan perjanjian yang telah disepakati. Pengukuran capacity dari calon debitur dapat dilakukan melalui berbagai pendekatan antara lain pengalaman mengelola usaha (business record) nya, sejarah perusahaan yang pernah dikelola (pernah mengalami masa sulit apa tidak, bagaimana mengatasi kesulitan). Capacity merupakan ukuran dari ability to pay atau kemampuan dalam membayar.

\section{Kapital}

Adalah kondisi kekayaan yang dimiliki oleh perusahaan yang dikelolanya. Hal ini bisa dilihat dari neraca, laporan rugi-laba, struktur permodalan, ratio-ratio keuntungan yang diperoleh seperti 
Bambang Winarso: Keberhasilan Pengembangan Ternak Sapi Potong Melalui Pola Pengembangan Modal

return on equity, return on investment. Dari kondisi di atas bisa dinilai apakah layak calon pelanggan diberi pembiayaan, dan beberapa besar plafon pembiayaan yang layak diberikan.

\section{Kondisi ekonomi}

Kredit yang diberikan juga perlu mempertimbangkan kondisi ekonomi yang dikaitkan dengan prospek usaha calon debitur. Ada suatu usaha yang sangat tergantung dari kondisi perekonomian, oleh karena itu perlu mengaitkan kondisi ekonomi dengan usaha calon debitur. Permasalahan mengenai Condition of economy erat kaitannya dengan faktor politik, peraturan perundang-undangan negara dan perbankan pada saat itu serta keadaan lain yang mempengaruhi pemasaran seperti Gempa bumi, tsunami, longsor, banjir dsb.Sebagai contoh beberapa saat yang lalu terjadi gejolak ekonomi yang bersifat negatif dan membuat nilai tukar rupiah menjadi sangat rendah, hal ini menyebabkan perbankan akan menolak setiap bentuk kredit invenstasi maupun konsumtif.

\section{Kolateral}

Adalah jaminan yang mungkin bisa disita apabila ternyata calon debitur benar-benar tidak bisa memenuhi kewajibannya. Collateral diperhitungkan paling akhir, artinya bila masih ada suatu kesangsian dalam pertimbangan-pertimbangan yang lain, maka bisa menilai harta yang mungkin bisa dijadikan jaminan. Pada hakikatnya bentuk collateral tidak hanya berbentuk kebendaan bisa juga collateral tidak berwujud, seperti jaminan pribadi (bortogch), letter of guarantee, rekomendasi. Penilaian terhadap kolateral ini dapat ditinjau dari 2 (dua) segi yaitu :

a. Segi ekonomis yaitu nilai ekonomis dari barang-barang yang akan digunakan.

b. Segi yuridis apakah agunan tersebut memenuhi syarat-syarat yuridis untuk dipakai sebagai agunan.

Sampai dengan akhir periode tahun 2010 masih ada kesulitan untuk memperoleh dan memanfaatkan KUPS. persyaratan ataupun mekanisme yang terkesan berbelit untuk mendapatkan KUPS. Penentuan akad kredit tetap di tangan pihak perbankan, sosialisasi program ke perbankan di daerah tentang KUPS juga belum maksimal, di daerah banyak yang tidak tahu menahu adanya program KUPS. Bahkan lebih dari itu kepala dinas peternakan yang kebanyakan tidak membantu dalam memberikan rekomendasi kepada pelaku usaha, untuk kemudahan dalam memperoleh KUPS. KUPS adalah kredit yang diberikan oleh bank pelaksana kepada pelaku usaha pembibitan sapi yang didukung dengan subsidi bunga oleh pemerintah (Jurnal Berdaya, 2010).

Kementerian Pertanian diprediksi gagal menambah populasi sapi dari program Kredit Usaha Pembibitan Sapi (KUPS). Program yang ditetapkan pada September 2009 itu mematok target penambahan 1 juta ekor sapi selama lima tahun (sampai 2014) atau 200 ribu ekor sapi per tahun. Nyatanya, hingga Februari 2013 total ternak yang bertambah dari program KUPS hanya 40.835 ekor sapi. Sedikitnya sapi baru yang dihasilkan tercermin dari seretnya penyerapan KUPS yang mencapai Rp 509,1 miliar sejak 2010 hingga 2013. Jumlah tersebut jauh dari komitmen pinjaman yang ditetapkan 11 perbankan sebesar Rp 3,96 triliun (Tempo, April 2013).

\section{Kinerja Bank Daerah Dalam Menyalurkan KUPS (Kasus Bank Nagari)}

Bank Nagari merupakan lembaga perbankan milik daerah Provinsi Sumatera Barat yang ditinjuk untuk menyalurkan kredit KUPS. Hasil evaluasi baki debet Bank Nagari yang dilakukan pada pertengahan tahun 2014 menunjukkan bahwa target kontrak untuk menyalurkan KUPS sampai dengan bulan Desember 2014 adalah sebesar Rp 59,45 milyar. Realisasi penyaluran KUPS sampai dengan bulan Juli 2014 telah mencapai Rp 47,28 milyar, artinya pada bulan tersebut Bank nagari telah mampu menyalurkan kredit KUPS sebesar 78,91\% yang tersalur lewat 26 cabang Bank Nagari di seluruh Sumatera Barat. Ini merupakan suatu prestasi yang sangat bagus jika dibandingkan dengan bank 
daerah di provinsi lainnya di Indonesia. Informasi dilapangan menunjukkan bahwa setidaknya 13,32\% angka pertumbuhan sampai dengan bulan ke tujuh di tahun 2014 ini.

Salah satu bank nagari yang punya prestasi yang cukup bagus dalam penyaluran kredit KUPS adalah Bank Nagari Cabang Tapan yang memiliki wilayah di Kabupaten Pesisir Selatan - Sumatera Barat. Bank Nagari Cabang Tapan merupakan salah satu lembaga bank Nagari yang "Berhasil" dalam penyaluran kredit KUPS. Keberhasilan tersebut ditunjukkan oleh besarnya dana kredit yang tersalur. Sampai dengan periode Juli 2014 dana KUPS tersalur adalah sebesar Rp 9,36 milyar yang disalurkan ke 25 kelompok peternak di wilayah ini. Besarnya pinjaman KUPS perkelompok berkisar antara Rp 200 juta s/d Rp 1,68 milyar. Sebanyak 4 (empat) kelompok peternak menerima kredit KUPS sebesar Rp 200 juta s/d Rp 250 Juta, 6(enam) kelompok menerima dana KUPS sebesar antara > Rp 250 juta s/d Rp 300 juta, 13 kelompok menerima dana KUPS sebesar Rp > Rp 300 juta s/d Rp 350 juta dan 2 kelompok peternak menerima dana KUPS antara > Rp 350 juta s/d Rp 1,68 juta. Dari sebanyak 25 debitur kelompok peternak yang mengambil kredit tersebut tergolong lancar semuanya dalam hal pengembalian angsuran maupun pembayaran bunga bulanan. Keberhasilan tersebut disebabkan karena adanya kerjasama yang baik antara pihak bank, dinas terkait (Dinas Peternakan dan Kesehatan Hewan) dan peternak. Dalam upaya mendukung keberhasilan usaha pembibitan peternak, pihak bank telah melakukan beberapa kegiatan kunci diantaranya adalah :

a. Melakukan sosialisasi dan pendekatan serta mendeteksi terhadap usaha bisnis (market inteligence) dan kebiasaan pengelolaan ternak calon peminjam (kelompok peternak).

b. Membantu pembuatan proposal kepada peternak yang masih awam dalam membuat proposal, serta membantu mempersiapkan kelengkapan proposal seperti KTP, kartu keluarga, serta kepastian surat agunan yang dimilki oleh calon debitur. Surat-surat agunan tersebut menyangkut sertifikat tanah/rumah maupun BPKB kendaraan roda 2 maupun roda 4. Hal ini perlu dilakukan guna mendapatkan sertifikat maupun BKPB asli. Kegiatan ini dilakukan guna mengantisipasi adanya sertifikat ganda maupun palsu serta nomor mesin kendaraan yang tidak sesuai dengan aslinya.

c. Keputusan terhadap pelaksanaan penyaluran KUPS didasarkan atas keputusan komite bank yang terdiri dari 4 pihak diantaranya adalah Ketua/wakil ketua pimpinan cabang, Seksi kredit, analis kredit dan seksi dana.

d. Keputusan permohonan KUPS dari kelompok peternak lebih ditekankan pada kemampuan bisnis pengelolaan/pemeliharaan ternak, kondite calon debitur, serta adanya incame tambahan selain usaha ternak sapi potong yang bisa diandalkan manakala usaha budidaya ternak sapinya mengalami kegagalan, maka kebutuhan ekonomi rumah tangga tidak ikut terganggu dengan adanya kegagalan tersebut.

e. Membantu pengembangan pakan hijauan terutama pengadaan bibit rumput King Grass secara gratis kepada peternak yang diambil dari alokasi dana CSR (Coorporate Social Responsibility) perusahaan.

f. Besarnya plafon KUPS yang akan disalurkan didasarkan atas Rencana Bisnis Bank (RBB) yang dibuat dan disesuaikan dengan ketersediaan plafon dana KUPS di kantor pusat.

Sementara keragaan penyaluran kredit KUPS yang dilakukan oleh Bank Nagari Cabang Tapan pada bebelapa kelompok peternak menunjukkan kinerja yang bervariasi. Dari beberapa kelompok peternak yang mampu merealisasikan bantuan kredit dan kelompok yang belum mendapatkan dana KUPS keragaannya sebagai berikut : 
Bambang Winarso: Keberhasilan Pengembangan Ternak Sapi Potong Melalui Pola Pengembangan Modal

\section{Kelompok yang belum merealisasikan pinjaman KUPS}

Kelompok peternak "Jambak Indah" yang berlokasi di Desa Bunga Pasang II, Kec. Empat Jurai, Kab. Pesisir Selatan merupakan kelompok peternak yang tidak/belum mengajukan KUPS. Kelompok yang dibangun sejak thn 2011 dan beranggotakan 12 orang peternak tersebut belum mengajukan KUPS lebih disebabkan karena ketidak tahuannya tentang apa itu KUPS. Kelompok peternak yang di motori oleh SMD dan telah mendapatkan dana program SMD tersebut telah mendapatkan bantuan dana SMD sebesar Rp 302 juta dan ternak sapi potong saat ini yang dikuasai sebanyak 42 ekor dengan pola usaha campuran antara pembiakan dan penggemukan.

Tidak mengajukannya KUPS oleh kelompok tersebut, disamping informasinya belum jelas juga hal lain yang menjadi ganjalan bahwa agunan merupakan hal yang masih menjadikan masalah. Sebab sebagian besar anggotanya tidak memiliki asset tetap (sawah dan rumah) yang memenuhi syarat untuk dijadikan agunan. Rumah yang dimiliki maupun lahan yang dikuasai belum memiliki sertifikat. Yang ada hanya sebatas surat keterangan, sehingga kelompok yang bersangkutan memberikan saran agar masalah agunan perlu dipikirkan solusinya. Mengingat kelompok peternak "Jambak Indah" sangat berminat untuk mendapatkan kredit KUPS guna pengembangan usaha ternak sapi potong agar bisa lebih berkembang lagi.

Sementara CV "Sungai Tawar" yang berlokasi di Desa Sungai Tawar, Nagari Setua Nangalo, Kec. Koto XI Selatan, Kab. Pesisir Selatan, merupakan perusahaan yang bergerak dibidang usaha pembibitan ternak sapi potong. Dimana jenis sapi yang dikembangkan, disamping sapi lokal (sapi pesisir), sapi Bali dan sapi PO. Awalnya perusahaan tersebut bergerak di bidang penggemukan (fattening) dan pembibitan ternak sapi potong dengan perbandingan usaha 50\% sapi fattening dan 50\% sapi pembibitan (pengembang biakan) yang dilakukan sejak tahun $2012 \mathrm{~s} / \mathrm{d} 2013$. Saat ini usahanya lebih difokuskan pada usaha pembibitan dengan alasan bahwa wilayah Kabupaten Pesisir Selatan masih kekurangan sapi-sapi bakalan yang akan dibesarkan/digemukkan. Saat ini perusahaan yang bersangkutan telah memiliki 150 ekor.

Fasilitas yang dimiliki perusahaan adalah lahan areal penggembalaan seluas 42 ha, 7 buah paddock dimana 1(satu) paddock dikhususkan untuk sapi betina bunting, areal tanaman rumput Taiwan seluas 10 ha. Untuk operasional usaha dan pengembangan usaha, perusahaan saat ini telah memanfaatkan dana KKPE dimana dana pinjaman yang pernah diajukan adalah sebesar Rp 200 juta. Mengingat dana KKPE yang didapat belum mencukupi, maka perusahaan yang bersangkutan sangat berminat untuk mendapatkan bantuan dana KUPS. Belum memanfaatkannya dana KUPS sebab selama ini belum ada informasi yang jelas tentang keberadaan kredit program KUPS yang memang diperuntukkan untuk pengembangan usaha perbibitan ternak sapi potong. Yang saat ini sangat diperlukan oleh perusahaan adalah adanya petugas perusahaan yang bisa melakukan kegiatan inseminasi (IB). Oleh karena itu dalam waktu dekat pihak perusahaan akan mengajukan permohonan ke Dinas Peternakan Propinsi Sumatera Barat, agar salah satu karyawannya agar bisa diikut sertakan dalam latihan inseminasi ternak sapi potong, disamping berupaya untuk mendapatkan bantuan modal KUPS.

\section{Kelompok Peternak Yang Telah Terealisasi KUPS}

Ada 5(lima) kelompok ternak sapi potong yang dalam pengajuan kredit KUPS dan telah terealisasi yang berhasil dikunjungi yaitu masing masing adalah (a) Kelompok peternak "Suka Maju", (b) Kelompok peternak "Sumber Mulyo" (c) Kelompok peternak "Mekarsari" dimana ketiga kelompok tersebut berdomisili di Desa TSM Talang Binjai, Kec. Silaut, Kab. Pesisir Selatan, (d) Kelompok peternak "Putra Simbal" yang berdomisili di Desa Padang Cupak, Kec. Lengayang, Kab. 
Pesisir Selatan, dan (e) Kelompok peternak “Tunas Harapan” yang berdomisili di Desa Limau Manis, Kec. Pauh, Kota Padang.

Dari hasil wawancara terhadap kelima kelompok peternak penerima KUPS tersebut bahwa secara umum menunjukkan kinerja yang bagus terutama dalam hal pembayaran bunga maupun cicilan pokok. Tiga kelompok peternak di Desa TSM Talang Binjai telah melunasi cicilan bunganya selama dua tahun dan bunga selama dua tahun tersebut telah dibayarkan di depan saat dana baru cair. Sementara Dua kelompok peternak lainnya yaitu kelompok peternak "Putra Simbal" dan Kelompok Peternak "Tunas Harapan" disamping telah melunasi bunga pinjaman sampai bulan terakhir (Agustus 2014) juga telah melunasi kewajiban cicilan tahun pertama dan tahun kedua. Keberhasilan dari kelompok peternak yang mendapatkan bantuan kredit KUPS tersebut tidak lepas dari pembinaan kedua lembaga penting yaitu Dinas Peternakan dan Kesehatan Hewan dan pembinaan dari Bank Nagari. Bahkan Bank Nagari melalui kebijakan CSR (Coorporate Social Responsibility) telah menyalurkan bantuan berupa pengembangan hijauan pakan ternak berupa bantuan bibit rumput gajah yang dibagikan langsung kepada kelompok peternak yang ada terutama di Desa Talang Binjai.

Yang menjadi permasalahan bahwa dengan adanya keberhasilan para peternak memanfaatkan dana KUPS dampak langsung yang dirasakan adalah semakin berkembangnya populasi ternak. Terutama untuk kelompok peternak di wilayah Desa TSM Talang Binjai, dimana diwilayah desa tersebut banyak terdapat kelompok peternak-kelompok peternak baik yang telah mendapatkan bantuan pemerintah maupun yang belum. Dengan semakin berkembangnya populasi ternak sapi potong sementara wilayah areal penggembalaan (kebun sawit) dan lahan tanaman rumput serta areal pencarian rumput alam terbatas, maka pakan ternak terutama hijauan sudah mulai menjadi masalah.

Kekurangan pakan tersebut lebih disebabkan karena rumput merupakan pakan andalan, sementara limbah sawit yang sebenarnya potensinya sangat besar belum dimanfaatkan sama sekali. Untuk itu peternak mengharapkan adanya bimbingan teknis tentang pembuatan pakan asal tanaman sawit maupun limbah industry sawit. Selain itu peternak mengharapkan bantuan Chopper (alat pencacah pelepah sawit) guna memenuhi kebutuhan pakan yang dirasa semakin berkurang. Dengan berkurangnya pakan tersebut, maka peternak mengalami kesulitan dalam mengembangan usaha budidaya ternak sapi potong kearah yang lebih besar.

Tabel Realisasi Responden Kelompok yang menerima KUPS di Sumatera Barat, 2014.

\begin{tabular}{rllllr}
\hline No & Nama Kelompok & \multicolumn{1}{c}{ Desa } & \multicolumn{1}{c}{ Kecamatan } & \multicolumn{1}{c}{ Kabupaten } & $\begin{array}{r}\text { Realisasi Kredit } \\
\text { (Rp 000) }\end{array}$ \\
\hline 1 & KSU-ED TABEK & Talang Babungo & Hiliran Gumati & Solok & 530.000 \\
2 & CBLS & Jr.Ps.B. Ngr Cepak & Gunung Talang & Solok & 636.000 \\
3 & Semapet Farm & Nagari Cupak & Gunung Talang & Solok & 1.500 .000 \\
4 & Nusa Fauna & Limo Manis Sltan & Pauh Padang & Padang & 500.000 \\
5 & Sumber Mulyo & Talang Binjai & Silant & Pesisir Selatan & 350.000 \\
6 & Suka Maju & TSM Talang Binjai & Silant & Pesisir Selatan & 350.000 \\
7 & Putra Simbal & Padang Cupak & Lengayang & Pesisir Selatan & 260.000 \\
8 & Mekar Sari & Talang Binjai & Silant & Pesisir Selatan & 350.000 \\
\hline \multicolumn{7}{r}{ T O T } & A L & & 4.476 .000 \\
\hline
\end{tabular}

Dalam upaya menekan resiko kegagalan usaha pembi bitan sapi potong di tingkat peternak maupun pengusaha, maka sangat penting untuk dilengkapi dengan fasilitas asuransi. Seperti diketahui bahwa Bank Indonesia dan Kementerian Pertanian bekerjasama dengan perusahaan asuransi 
meluncurkan skema Asuransi Ternak Sapi. Program ini merupakan salah satu implementasi dari Nota Kesepahaman yang terjalin antara kedua lembaga sejak 2011, yang bertujuan mendorong peningkatan akses kepada sumber-sumber pembiayaan untuk usaha di sektor pertanian. Karakteristik usaha sektor pertanian, khususnya subsektor budidaya dan pembibitan sapi, dianggap berisiko tinggi karena bersifat biologis yang rentan terhadap serangan penyakit dan kematian, sehingga dapat menyebabkan kerugian. Asuransi ternak sapi memberikan jaminan penggantian kepada pemilik jika ternak sapi mengalami risiko kematian karena penyakit, kecelakaan dan melahirkan maupun risiko kehilangan atau lainnya sebagaimana diatur di dalam polis.

Asuransi ini memberikan perlindungan terhadap atas risiko kerugian baik bagi peternak maupun perbankan. Adanya produk asuransi ini juga diharapkan dapat mendorong pendalaman industri asuransi dan perbankan secara umum dan menjadi momentum pengembangan asuransi sektor pertanian di Indonesia. Pada akhirnya, peluncuran produk ini diharapkan akan meningkatkan posisi tawar peternak dalam rangka mengakses sumber kredit/pembiayaan, dan di sisi perbankan akan meningkatkan penyaluran kredit ke sektor pertanian karena sebagian risiko kegagalan telah diproteksi oleh asuransi (Jurnal Pertanian, 27 Oktober 2013).

\section{Evaluasi Keberhasilan Program KUPS di Sumatera Barat.}

Untuk melihat sampai sejauh mana tingkat keberhasilan penyaluran kredit KUPS di wilayah Sumatera Barat lewat Bank Nagari, maka pihak Bank Nagari terutama Bank Nagari Cabang Tapan telah melakukan evaluasi kegiatan penyaluran KUPS yang selama ini telah dilakukan. Dilihat dari besarnya KUPS yang berhasil disalurkan, sampai dengan periode Maret 2014 Bank Nagari Cabang Tapan telah mampu menyalurkan kredit KUPS sebesar Rp 9,26 milyar yang tersalur ke 28 kelompok peternak. Dilihat dari jumlah ternak sapi potong yang bisa diadakan pada awal pemanfaatan dana KUPS oleh kelompok peternak adalah sebanyak 721 ekor. Dan saat ini jumlah ternak tersebut telah berkembang menjadi 871 ekor, artinya mengalami perkembangan jumlah ternak sebesar 16,49\%.

Evaluasi perkembangan ternak selama ini (sejak adanya KUPS) menunjukkan bahwa dari induk yang dibeli awal sebanyak 721 ekor sebagian telah dijual (32 ekor) karena mengalami kemajiran dan mati sebanyak 22 ekor, sehingga total induk saat ini adalah sebanyak 667 ekor. Sementara selama kurun waktu tersebut pedet yang dilahirkan adalah sebanyak 228 ekor yang terdiri dari pedet jantan 132 ekor dan pedet betina sebanyak 96 ekor. Dari jumlah tersebut pedet yang mati sebanyak 16 ekor yang kesemuanya adalah betina sedangkan pedet yang dijual sebanyak 8 ekor yang kesemuanya jantan. Keadaan jumlah ternak terakhir adalah sebanyak 871 ekor. Dilihat dari mekanisme perbibitan, secara umum kelompok yang mendapatkan bantuan modal KUPS tersebut telah mampu melakukan pembudidayaan dengan baik artinya usaha tersebut telah berkembang positif setidaknya dilihat dari perkembangan jumlah ternak sapi yang ada. Akan tetapi secara teknis pembibitan, maka kelompok yang mendapatkan bantuan KUPS tersebut belum memenuhi syarat. Pencatatan dan penimbangan ternak yang lahir masih banyak yang belum melakukan, disamping itu pemasangan "Chip" hampir semua kelompok belum melakukannya. Untuk itu pembinaan kearah tersebut masih perlu diupayakan dengan lebih serius agar misi KUPS sebagai pengembangan perbibitan ternak sapi potong dapat tercapai.

\section{KESIMPULAN}

Program pengembangan ternak sapi potong melalui kebijakan bantuan modal berupa kredit KUPS tampaknya belum bisa diharapkan dengan banyak. Permasalahannya adalah ketatnya 
Jurnal Penelitian Pertanian Terapan

persyaratan bank terutama dalam hal agunan. Hal ini logis mengingat bank selaku pelaksana penyaluran dana pinjaman yang memang berasal dari bank itu sendir perlu bertindak secara hati-hati dan selektif. Akan tetapi tidak semua kelompok penerima program mengalami hal yang sama. Kasus di Sumatera Barat menunjukkan bahwa program KUPS ternyata mampu meningkatkan kinerja usaha kelompok peternak. Keberhasilan tersebut tidak lepas dari usaha bersama antara pihak bank, Dinas Peternakan dan Kesehatan Hewan dan Kelompok peternak untuk secara bersama-sama berusaha secara sinergi menuju keberhasilan program. Namun demikian masih ada kendala untuk menuju usaha perbibitan yang sesuai dengan standar teknis perbibitan.

\section{SARAN :}

Sebagai tindak lanjut adalah perlu adanya sinergitas Program Kerja Bersama dalam Kementerian Pertanian itu sendiri yaitu , (a) Pelatihan untuk meningkatkan kapasitas usaha kelompok peternak calon nasabah agar menjadi feasible dan bankable, (b) Sosialisasi untuk meningkatkan pemahaman tentang KUPS perlu lebih disosialisasikan. Atas usaulan kelompok bahwa KUPS seyogyanya tidak dibatasi selama 5 tahun, melainkan 7 tahun hal ini penting, karena kurun waktu 5 tahun dianggap terlalu pendek bagi usaha bisnis pembibitan sapi potong.

\section{DAFTAR PUSTAKA}

Afandi P. ; Analisis Implementasi 5C Bank BPR Dalam Menentukan Kelayakan Pemberian Kredit Pada Nasabah; Jurnal Among Makarti Vol. 3. No. 5 Thn 2010.

Bank Indonesia. 2012. Peranan Bank Indonesia dalam Menyalurkan Kredit Program Pemerintah.

Daud Sinjal; Perlu Lembaga Penjaminan KUPS ; Agrina 2011

Ditjend Peternakan dan Penyakit Hewan, 2014 Realisasi Penyaluran KUPS Di Indonesia

Inpres No.1/2010. Tentang Percepatan Pelaksanaan Prioritas Pembangunan Nasional.

Jurnal Berdaya , 2010; Berpikir Positif Memberdayakan Masyarakat Desa Dan Marjinal Pelaku Usaha Sulit Ajukan Kredit Usaha Pembibitan Sapi

Jurnal Pertanian, Minggu, 27 Oktober 2013 Asuransi Ternak Sapi Diluncurkan Bank Indonesia Dan Kementan.

Kememterian Negara Koperasi dan Usaha Kecil dan Menengah; Informasi Skema Pembiayaan Bagi Usaha Kecil Menengah Koperasi Pelaku Ekspor; Deputi Bidang Pembiayaan Asdep Urusan Asuransi dan Jasa Keuangan, 2009.

Peraturan Menteri Keuangan No. 131/PMK.05/2009. Tentang Kredit Usaha Pembibitan Sapi (KUPS), tanggal 18 Agustus 2009

Permentan No. 36/Permentan/Ot.140/8/2006. Tentang Sistem Perbibitan Nasional

Permentan No. 40/Permentan/PD.400/9/2009. Tentang Pedoman Pelaksanaan KUPS, tertanggal 8 September 2009

Republika Online, 2014. BNI Kucurkan Kredit Pembibitan 3.000 Ekor Sapi 
Bambang Winarso: Keberhasilan Pengembangan Ternak Sapi Potong Melalui Pola Pengembangan Modal

Tempo edisi Senin 15 April 2013. surabayapost.co.id/tempo.co 15 April, 2013 by Pembibitan sapi terancam gagal

Undang-Undang No 18/2009. Tentang Peternakan dan Kesehatan Hewan 